\title{
Names of Accents and Diacritical Punctuation Signs in Poems by North African Jewish Poets *
}

Rachel MASHIAH

Bar-Ilan University

In several Sephardi printed editions of the Pentateuch one can find a list of thirty-four names of signs: twenty-nine names of accents in the Twenty-One Prose Books (including Pasec, Macaf and $G a^{\prime} y a$ ); four names of diacritical punctuation signs: Dagues, Rafe, Mapic and Šibolet / Sibolet (for Šin and Sin); and Ševa. This list is called the Zarca List, named after its opening accent.

The Zarca List has been referred to in various poems written by Jewish North African poets. Some added flair to their poems by incorporating idiomatic phrases based on names of accents, ${ }^{1}$ and several based an entire poem on that list. I have come across only four poems belonging to the latter category:

- פלאך קיוויתי - written by the sixteenth century Tunisian poet Fradji Shawat, and based on thirty-one names of signs (commentary by E. Hazan ${ }^{2}$ ); וי כי חזקה האמ-written by the nineteenth century Moroccan poet Shmu'el Elbaz, and based on thirty-two

\footnotetext{
* Several issues discussed in this paper were presented at the Fourteenth International Congress of Masoretic Studies (IOMS) 1998. I would like to thank Prof. Aron Dotan, the president of IOMS, for reading that paper and providing very insightful comments.

1 For examples, see HAZAN 1987, pp. 367-375.

2 HAZAN 1976, pp. 95-97; see also idem 1987, pp. 374-375; idem 1995, pp. $220-222$.

Sefarad 62 (2002) págs. 349-368

(c) CSIC

ISSN 037-0894
} 
names (commentary by Sh. Adary ${ }^{3}$ ); קודר הילכת - probably written by the nineteenth century Moroccan poet Amram Bar-Yehuda Elbaz, ${ }^{4}$ and containing twenty-seven of the names (commentary by Ch. R. Shoshanna 5); and אהה עלי כי נקף - written by the nineteenth century Moroccan poet Rafael Aaron Monsoñego ${ }^{6}$ (commentary by R. Mashiah and T. Lavi ${ }^{7}$ ).

In all four poems both literal and figurative meanings may be ascribed to the names of the signs. This paper focuses on Monsoñego's use of the Zarca List in the elegy אהה עלי כי נקף, and compares it with the aforementioned poems. ${ }^{8}$

The epigraph preceding אהה עלי כי נקר (תחק marks the poem as an

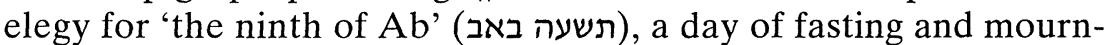
ing, the day on which the First and Second Temples were destroyed. It also alludes to the fact that the poem is based upon names of accents through the phrase ותעש גם היא מטעמים, where the word מטעמים, from the root טע"ם, may be interpreted as 'accents'.

The rhyming in this elegy follows the poet's Jewish-Moroccan dialect, ${ }^{9}$ and it is therefore possible to find rhymes such as עובר / תבִיר (צירי/חיריק) (lines 3,4) which demonstrate the elimination of the phonemic contrast of /i/ and /e/ in this dialect; שיון/סמ"ך) גרשין / יוחסין) (lines 23,24) demonstrate the elimination of the phonemic contrust of /s/ and /š/; שיון/צד"י) תלשא / (lines 27,28) demonstrate the weakening of the emphatic consonant/ș/; רפה/דגש) עובר / שיבר (b) (lines 3,5) which might indicate the explosive pronunciation [b] in both cases; and and סגולתא/עיפתה (מלרע/מלעיל) (lines 2,14) both pronounced מלרע

\footnotetext{
3 ADARY 1997, pp. 207-209.

${ }^{4}$ A poem from the well-known collection שיר ידידות which is read or sung by Moroccan Jews on Friday evenings.

${ }^{5}$ SHOSHANNA 1983 , pp. 322-324.

${ }^{6}$ Rabbi Rafael Aharon Monsoñego (1760-1840) wrote a collection of 90 poems titled נאות מדבר «Oasis» (as yet unpublished).

7 MASHIAH and LAVI 1998, pp. 63-65.

וי כי חזקה and קודר הילכתי ,פלאך קיוויתי appears on pages 354-356 8 אהה עלי כי נקף האמה 8 האמה are quoted in the appendix.

${ }^{9}$ For reference to North African dialects see, e.g., KATZ 1978 (especially pp. 18-20, 62, 126); SCHIRMANN 1961, II, p. 734; HAZAN 1976, pp. 48-49; HAZAN 1989 , pp. $78-79$.

10 Similar rhyming, reflecting the poets' North African dialects, can be found

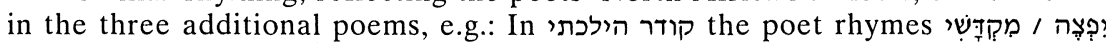

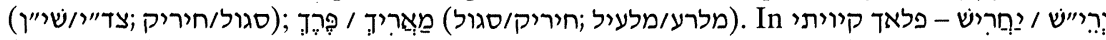

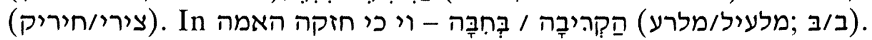


While the original text has no vocalization signs, ${ }^{11}$ the marks «Gueršayim» inserted in most of the of accents and diacritical-sign names, are part of that manuscript (and indicate the presence of the calembour). ${ }^{12}$

The second line in the opening verse ${ }^{13}$ is quoted directly from the Zarca List: the name of the disjunctive Zarca (from the root זר״ק) can be understood literally as 'throwing'; Macaf from נק" ('to knock') is a connective sign that prevents the word preceding it from having independent status; and Šofar-Holej is one of the types of accents that were called by the name שופר ('trumpet', 'horn'), and is equivalent to מונח (an abbreviation of שופר מונח). As for the Segolta (Segol) ${ }^{14}$, the poet uses the sound of the word as an זרקא מקף the chosen people. The whole phrase (1) שופר הולך סגולתא (can be read in several ways: «the chosen people (עם סגולה) are thrown (זרקא) out of their country and promised land to be scattered all over the world». The expression זרקא מקף שופר alludes to the people's disaster, where the Macaf strikes the 'trumpet' (שופר), a symbol of Israel, and injures it. The phrase זרקא מקר can also refer to the destruction of the Kingdom of Judea, as the Zarca becomes a Macaf which represents the annihilation of the people's independent existence. The names of these signs also lend themselves to an additional interpretation where the Zarca Macaf - «throwing a Blockade», refers to the seige around Israel (Segolta) that causes its 'beauty' (Šofar) to fade away and vanish (Holej). These various readings of the opening verse complement each other to create a multidimensional illustration of the disaster that befell the people of Israel.

The first strophe is based on four names of accents: the rare conjunctive Yare'ah ben-Yomo; Darga - 'grade' 'stair,' 'degree', from the root דר"ג; Tevir - Aramaic, from תב"ר 'broken' (שבור) which illustrates Israel's fall; and the conjunctive Šofar Mehupaj 'inverted trumpet'. In this strophe the names of the accents enhance the contrast between the people's past and present situation: in line 3 the people of Israel are compared to 'a new moon' (ירח בן־יומו) as if the chosen

\footnotetext{
${ }^{11}$ It was added here following the biblical system. I would like to thank my colleague, Dr. Z. Bstzer for his insightful remarks concerning the punctuation of the words: לעמוח (line 13), להיה (line 35).

12 Some form of pun, ascribing additional meaning (see HAZAN 1995, p. 88).

${ }^{13}$ Which functions as a prologue (anticipating the entire poem).

${ }^{14}$ From Aramaic: 'cluster' (of grapes).
} 
people were worthy of a unique status similar to that of the moon at the beginning of each month. The destruction of the Temple however transforms this holy day into a day of shame and disgrace, and similarly the people of Israel become 'a reproach in the sight of all that pass by' (חרפת כל עובר). This fall can also be traced in line 4, אחרי דרגא (תarga תביר, as the Darga (which represents a high status) is followed by a Tevir (break). In line 5 the people of Israel are compared to an 'inverted trumpet' (שופר מהופך), to indicate the disorder in the people's course of life.

The second strophe deals with one accent only, the Great Pazer (פזר גדול), from the root פ'scattering', ${ }^{15}$ an allusion to the Diaspora. קרני Although in some places Pazer is called פזר קטן (Little Pazer) and פזר גדול (Great Pazer), this is not the case here, and this name simply refers to Pazer and not to קרני פרה.

The third strophe is based on the phrase מאריך טרחא אתנח: Atnah derives from נו"ח 'rest', 'pause', but it can also be understood as 'sigh' as if it were derived from the root מאנחה); Ma'arij (מירכא in in ' Ashkenazi list) derives from אר״ך 'to prolong'; and Tarha, the Sephardi name for טפח which precedes Atnah as well as Siluc. ${ }^{16}$ This name derives from the root טר"ח 'laboring', and is interpreted here as 'burden' or 'trouble'. Thus the 'burden' (טרחא) and 'prolonged' (מאריך) suffering lead to 'groaning' (אתנח). Atnah may also be interpreted as 'to stay', as if to say - the burden 'stays' (in the sense of 'remains', 'does not leave').

The fourth strophe lists three names of accents and two names of diacritical signs: Gueriš 'banished', 'expelled'; Revi'a' - Aramaic from רב"ע 'couched' (רבוץ); and Yetiv - Aramaic from ית"ב 'settled down';

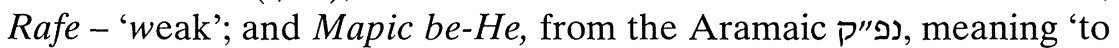
utter' the sound of the consonant ה"א The Revi'a' and the Yetiv represent Israel's past position, as the Revi'a' (couching) alludes to Judah, a lion's whelp (as Jacob blesses his son: «Ju'dah is a lion's whelp [...] he couched as a lion» [Gen. 49:9]), and the Yetiv symbolizes the people of Israel in their promised land. Thus the day of destruction is the day Judah is 'banished' (גריש) from its land, and once banished it is weak (רפה) and powerless. מפיק בה' משמיע corresponds to the 'act of

\footnotetext{
${ }^{15}$ Originally the name of this accent is Aramaic: פזרא = 'whip'.

16 In ancient sources only טפחא preceding אתנח is called «טרחא", see DOTAN 1967 , p. 155,335 note 25 .
} 
sighing' as the ['ha, ha'] sound of the sigh resembles the sound of the consonant ה"א.

The names of accents in the fifth strophe symbolize the destruction of the First and Second Temples: Tre-Ta'min - the Sephardi name for the rare conjunctive מירכא כפולה (Double Merja) - from טע"ם, means 'two reasons' for the prolonged suffering; Cadma from קדרים, is the Sephardi name for the disjunctive פשטא, and similarly Tre-Cadmin is פשטא which appears twice in penultimate words ${ }^{17}$ - both mean 'since then', since the destruction; Azla - Aramaic from 'going on', represents the 'walking' to exile, and may also indicate the people's 'helplessness' (אזלת יד) in the face of disaster; and the rare disjunctive Carne-Para (cow-horns) can be understood as representing the enemy and its evil, harmful force. In this strophe the poet magnifies the sense of pain and suffering by using symbols that incorporate a double element: תרי־טעמין, תרי־קדמין, חמי חמין, תרי אִמין, זיבורה ועקרבתא and קרני פרה.

The sixth strophe deals with Pasec - Aramaic from פס" 'cutting', which is used here in the judicial meaning of 'sentence', 'decree'; Two Gerašin (שני גרשין), גרשיים 'to from גריש' 'toxpel'; and Šalšelet 'chain' in the sense of 'ancestry', 'dynasty'. The poet joins these signs together to create a metaphor for the expatriates, where the Two Gerašin represent two cases of banishment, two exiles, 'sentenced' (פסק) by the Lord: the first exile forced upon מורשה קהילת יעקב (Jacob's sons, the tribes of Israel), and the second on those who returned from Babylon (שלשלת יוחסין). ${ }^{18}$

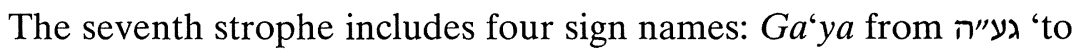
cry aloud'; the disjunctive Talša, equivalent to the Ashkenazi תלישה גדולה (Great Těliša) - from תליש 'uprooting'; once again Yetiv; and Tirṣa the Sephardi name for תלישה קטנה (Little Teliša) - from the root רצ"ה, 'to want' and 'to please'. Tirsa may also be interpreted here (as in Songs of Songs) as the 'Lord's beloved': «Thou art beautiful, O my love, as Tir'za» [6:4]. Thus the poet's soul, like the people of Israel compared to Tirsa - has been 'uprooted' (תלשא) from its place, from the land of Israel, and could not find a place to 'settle in' (ניביב); it therefore 'cries' (געיה). Two other interpretations of יתיב תרצה deal with Israel's inability to find a suitable place where it would be

17 The name פשט does not appear in this list.

${ }^{18}$ As they are listed in Esr. 8. 
'wanted' (רצוי), and with the fact that it is not yet time to 'please' (לרצות) Israel with return to its land.

In the eighth strophe Monsoñego mentions four names: Siva for שבא (written in this list with בי"ת rather than וו"ו (זקף גדול); Great Zaquef Sibolet, which appears in the Sephardi list to mark the difference between שיו" שי last strophe the poet uses the names of the signs to express his hope for salvation. The Lord is asked to gather his people (שיבולת פזורה), analogous to the current of the river (or the scattered seeds from an ear of corn), and 'lead them back' (שיבה) with 'upright' and proud bearing (זקף גדול) to their land. Sof-Pasuc suggests the 'end' of exile.

The poet closes a circle through the accents in the poem. The Great Pazer and the Šofar Mehupaj, representing the sorrow and grief of exile (in the first and second strophes), are confronted at the end ${ }^{20}$ with Great Zaquef as well as with the expression 'Great Šofar'

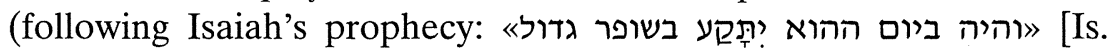
27:13] 'the great trumpet shall be blown') to symbolize future salvation.

Epigraph:גם זו לט״ב מר לה. ותעש גם היאמטעמים כי נהפך מתוק למר בין העמים

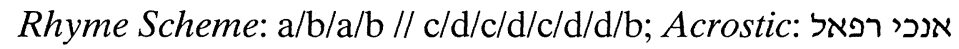

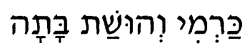

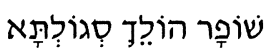

$$
\begin{aligned}
& \text { הָיָה חֶרְַּת כָּל עוֹבְר }
\end{aligned}
$$

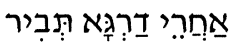

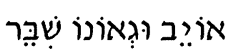

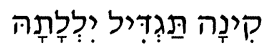

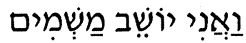

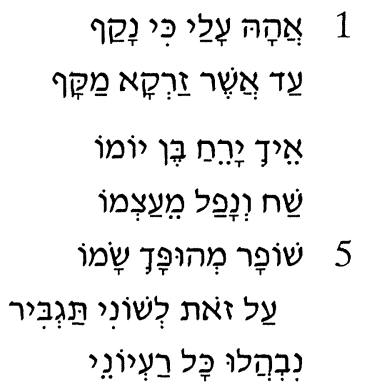

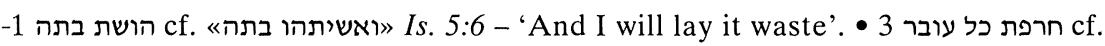
« Ez. 5:14 - 'and a reproach ..., in the sight of all that pass by'. • 4

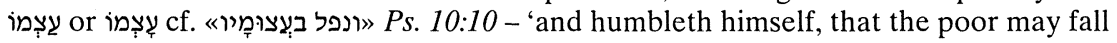

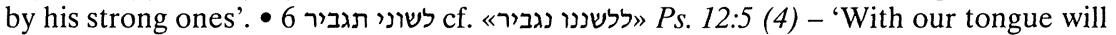

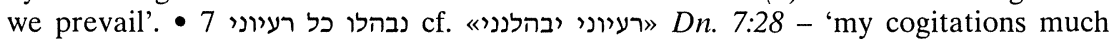

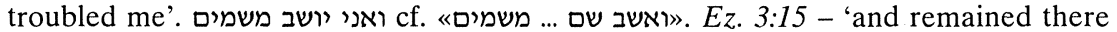
astonished'.

${ }^{19}$ There is no זקר קטון in this poem.

${ }^{20}$ In the last strophe and in the epilogue.
} 
Sef 62:2 (2002) NAMES OF ACCENTS AND DIACRITICAL PUNCTUATION SIGNS IN POEMS... 355

$$
\begin{aligned}
& \text { מִטוֹרֶפֶת תוֹך בַיְּים }
\end{aligned}
$$

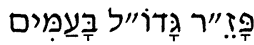

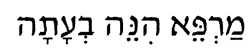

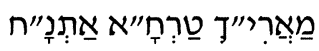

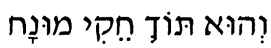

$$
\begin{aligned}
& \text { וּרְמַר }
\end{aligned}
$$

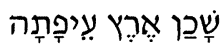

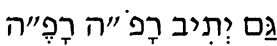

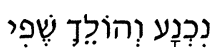

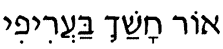

$$
\begin{aligned}
& \text { וַעִלָטָה הָיָתָה }
\end{aligned}
$$

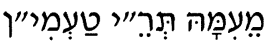

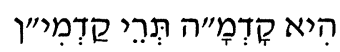

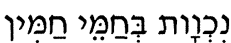

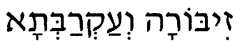

$$
\begin{aligned}
& \text { עַל מוֹרָשָׁה קְהַַלַת }
\end{aligned}
$$

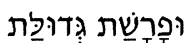

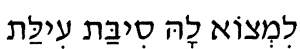

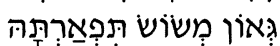

\author{
הָייתחִי כְּמוֹ אָנִי

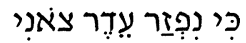 \\ 10

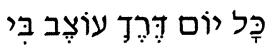

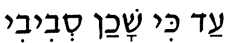

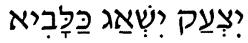

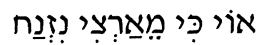

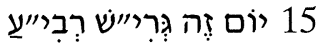

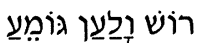

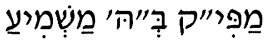

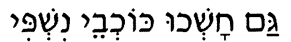 \\ רוֹשׁ וְלַען וּמָרָה

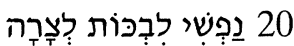

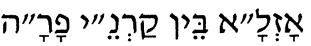

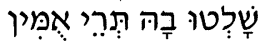

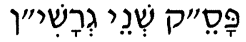

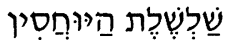

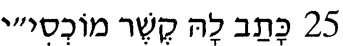

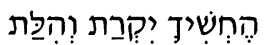

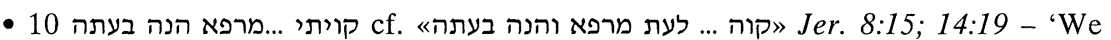

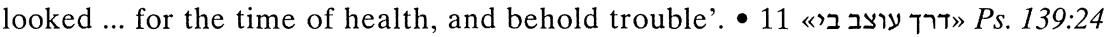
- '...any wicked way in me'. • ישאג כלביא 13 cf. שאגה לו כלביאת Is. 5:29 - 'Their roaring

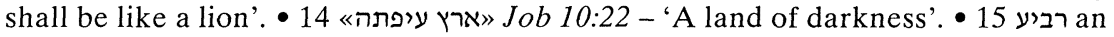
גור אריה יהודה ... כרע״ : גרוע : allusion to Ju'dah, a lion's whelp, as Ja'cob blesses his son

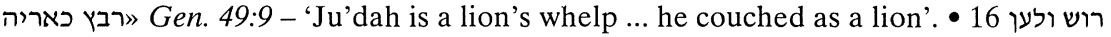

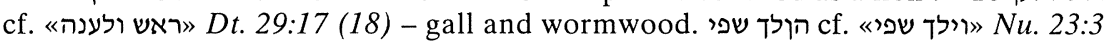

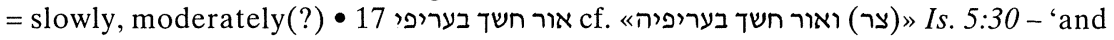

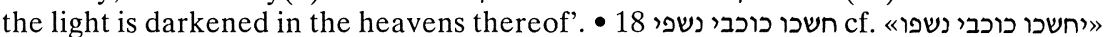

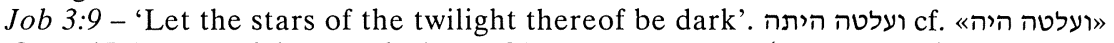
Gen. 15:17 - 'and it was dark'. - 22 (דבורה ועקרב) זיבורה ועקרבחא - bee and scorpion, an appellation for Babylon and Rome, the two nations responsible for Israel's destruction and exile. • מורשה קהלת יעקב" Dt. $23: 4$ - «the inheritance of the congregation of Ja'cob». • 24 «ופרשת גדלת מרדכומית Es. 10:2 - «and the declaration of the greatness of Mor'de-cai». • קשר מוכסין - a document vouching

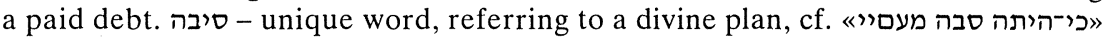

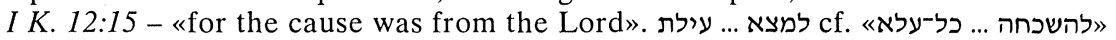

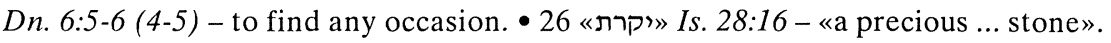
משוש תפארתה cf. «משוש תפארתם Ez. 24:25 - «the joy of their glory». 
Q: to shoot arrows; $P$ : to stone and to spit (as acts of humiliation and attack); $V$ : to spit; $A$ : - to throw; - to be thrown out (the people of Israel are thrown out of their country); - king.

2. מקף: from נקק", «binder»; referring to the duty of the sign.

$Q$ : surounding; $P$ : defending walls; $V$ : blockade, siege; $A$ : symbolizes the annihilation of Israel's indipendent existence; - to knock down, strike, beat up; - blockade, siege.

3. מונח = שופר :שופר הולך; referrumpet», the Sephardi name for to the form of the sign.

Q: שופר - a symbol of beauty (of Israel), שופר הולך - the beauty vanishes; $P$ : the messiah's trumpet; $V$ : a trumpet that lost its beauty; $A$ : - a symbol of Israel; - the beauty vanishes.

4. סגולתא: Aramaic: «cluster» (of grapes); referring to the form of the sign.

Q: an allusion to עם - עם סגולה - the chosen people = Israel; $P$ : an allusion to . ..... A: an allusion to allusion to עם סגם סגולה סגולה

5. פזר גדול: Aramaic: פזרא = «whip»; referring to the form of the sign.

$Q$ : from פזר, to scatter; an allusion to Israel's displacement; $P$ : from פזיר, to scatter... V: from פזיר, to scatter... A: from scatter...

6. ירח בן יומו: «a day old moon» (new moon); referring to the form of the sign.

Q: new moon; $P$ : an allusion to the messiah; $V$ : new moon; $A$ : Israel is compared to a new moon - the symbol of rebirth and fertility.

7. קרני פרח: «the horns of a cow»; referring to the ancient form of the sign.

Q: פרני = a a cow; $P$ : a cow, an allusion to the people of Israel in the Diaspora; $V$ : resemblance in the act of falling, where the descending moon beans correspond to a cow whose horns were removed; $A$ : an allusion to the enemy and its harmful forse.

8. געיה: from גע"ה, «to low», «cry aloud»; referring to the way of the performance. 
$Q$ : lowing; $P$ : lowing, crying aloud; $V$ : a misleading call (line 15); crying aloud (line 42); A: crying aloud.

9. תלשא: from תל"ש, «to pluck out»; might refer to the hand movement. Q: to be uprooted from the Land of Israel; P: the uprooted people; V: to pluck (hair); A: to be uprooted as an emotional displacement.

10. אזלא: Aramaic: «to go on»; perhaps because it often occurs before גרש.

$Q$ : aspectual verb: becoming; $P$ : to pass away, cease; $V$ : aspectual verb: becoming; A: - to be exiled; - from Hebrew: אזיל, weakness helplessness, impotence (אזלת יד).

11. גריש: from שריש, «expulsor»; referring to the duty of the sign.

$Q$ : to expel the enemy; $P$ : banishment; $V$ : to banish, exiling the people of Israel; $A$ : to be cast away, banished, the people of Israel were exiled.

12. pos: Aramaic: «to cut»; referring to the duty of the sign.

Q: to sentence, decree; P: from Heb. פספיק: to stop, cease; V: from Heb. פס" to stop, cease; A: to sentence, decree.

13. רביע: Aramaic: (רב״ע (=רב"ץ, «to rest», «crouch», «lie down»; perhaps referring to the position of sign (in contrust to זקר).

$Q$ : to lie down like a lion - a symbol of the enemy; $P$ : to crouch, stay in the Diaspora; $V$ : to lie down like a lion - a symbol of the enemy; $A$ : to lie down peacefully like a lion - a symbol of Israel.

14. שופר מהופך: the Sephardi name for מהפך; referring to the form of the sign.

Q: to convert the beauty (of the enemy) into ugliness; $P$ : שופר = trumpet, מהופך = to convert in the sense of «changed fate»; V: שופר = a symbol of beauty, שופר מהופך= Israel's beauty turns ugly once it becomes the property of the enemy; $A$ : a symbol of disruption and disorder in Israel's course of life.

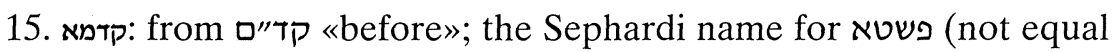
to the Ashkenazi אזלא = קדמא, see 10).

$Q$ : before, before the distruction of the temple; $P$ : before, the people of Israel followed the «Mizvot» before all other nations; $V$ : before, the 
people of Israel followed the «Mizvot» before all other nations; $A$ : since then, since the destruction.

16. תרי קדמין : פשטא whe Sephardi name for comes twice in penultimate words. see קדמא (15).

$\checkmark$ : twice earlier, the people of Israel followed the «Mizvot» long before other nations; $A$ : like קדמא (see 15), with specific reference to the destruction of the first and second temples.

17/18 זקר קטן/גדול: from זקול, «erect», «upright»; referring to the hand movement or to the form of the sign.

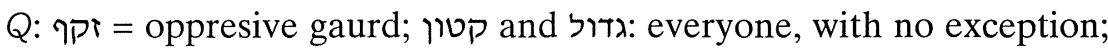

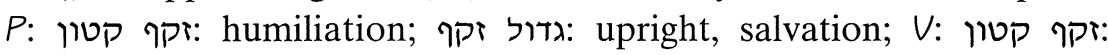

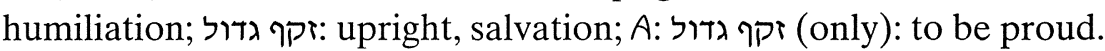

19. שלשלת: «chain»; referring to the form of the sign or of the melody.

$Q$ : a chain, noose, tied tight around the neck (for killing); $P$ : a chain, an allusion to the anger of the Lord; $V$ : ancestry, geneology, dynasty ; $A$ : ancestry, geneology, dynasty.

20. שני גרישין: גרשיים (see גריש (11).

$Q$ : reference to the two exiles; $P$ : reference to the two exiles; $V$ : in contrast to גריש (see 11), to drive the enemy out with magnified efficacy (double portion); A: like גריש (see 11), with specific reference to the two exiles.

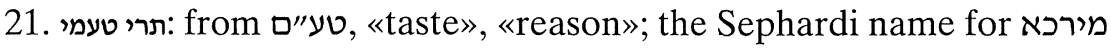
כפולה see מארי (24).

$Q$ : taste, bitter taste caused by two different plants; $P$ : taste, the good taste (of life) during the periods of the first and second temples; $V$ : taste, bitter taste caused by two different plants; A: two reasons.

22. דרג: «grade», «step», «stair», «degree»; referring to the form of the sign (or to the melody: Aramaic: daraja = to sing quaveringly).

$Q$ : high status, high position; $P$ : high status, high position; $V:$ extremely severe (punishment); $A$ : high status, high position.

23. תביר: Aramaic: תב״ר (= שב"ר «broken»; referring to the melody.

$Q$ : destruction of Israel's beauty; P: collapse; A: collapse. 
24. מאריך: from אר״ך, "prolonging»; the Sephardi name for מירכא.

$Q$ : prolonged suffering; $P$ : prolonged suffering; $V$ : prolonged suffering; $A$ : prolonged suffering.

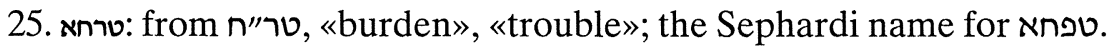
$Q$ : hard work, burden, trouble of exile; $P$ : hard work, burden, trouble of exile; $V$ : hard work, burden, trouble of exile; $A$ : burden, trouble of exile.

26. אתנח, נו"ח fto rest»; referring to the duty of the sign.

$Q$ : to rest peacefully; $P$ : rest and tranquility; $V$ : rest, pause; $A$ : - to overstay; - from אנאו, to sigh.

27. רפא, (רפ״ה :weak»; diacritical sign; referring to way of performance.

$Q$ : feeble, powerless; $P$ : emotional weakness; $V$ : feeble, powerless; $A$ : feeble, powerless.

28. שגד: Aramaic: degaš = «to pierce»; diacritical sign referring to position of sign.

$P$ : hard work, burden, trouble of exile.

29. יתיב: Aramaic: ית"ב (=יש״ב,, «settled down»; referring to melody or duty (pause).

$P$ : to sit, reference to the enemy; $V$ : from Hebrew: שו"ב, bring back the people of Israel; $A$ : - from יש"ב, allusion to Israel's safe, assured dwelling on its land (line 15); - from Hebrew: שו"ב, to return, bring back (line 28).

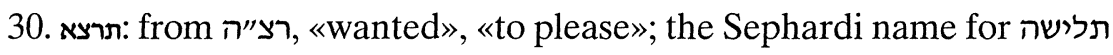
קטנה

$P$ : a symbol of Israel; $V$ : to want, to please; $A$ : a symbol of Israel.

31. שבולת/שבולת: mnemonic device for שיש:

$P:$ an allusion to the fall of the enemy: it will dry like an ear-of-corn and be washed down the river; $V$ : an ear-of-corn, reference to the enemy; $A$ : an allusion to Israel's dispersed state which resembles a channel of a river, or seeds scattered from an ear-of-corn.

32. מפיק בהיא: Aramaic: נפיק, to utter the sound; diacritical sign; referring to the performance. 
$P$ : to produce; $V$ : bring out, send away; $A$ : the act of sighing (sound resemblance).

33. שבא: שווא borrowed from the punctuation sign accentuation system; šewaya $=$ divisional accent.

V: from שו"ב: שובה: to come back; from שו"ב, to return, bring back.

34. סוף פסוק: «end of verse»; another name for סולוק.

$V$ : to put an end, say enogh; A: symbol of the end of exile.

Monsoñego uses almost all the names of the signs appearing on the Zarca List (except for Dagueš and Zaquef Caton), yet he changes their order. This is not the case in the three other poems mentioned above (by Fradji Shawat, Shmu'el Elbaz and Amram Bar-Yehuda Elbaz), in these three poems the order of the list is strictly followed. ${ }^{23}$ The following table illustrates this point:

The Order of Sign Names in the Sephardi Zarca List \& Poems

\begin{tabular}{|c|c|c|c|c|}
\hline אהה עלי כי נקף & וי כי חזקה האמה & פלאך קיוויתי & קודר הילכתי & Zarca List \\
\hline (=) זרקא & (=) זרקא & (=) זרקא & (=) זרקא & 1. זַרְקָא \\
\hline (=) מקף & (=) מקר & (=) מקף & (=) מקף & 2. מַקָּף \\
\hline (=) שופר הולך & (=) שופר הולך & (=) שופר הולך & שופר הולך & 3. שוֹפָר הוֹלְד \\
\hline סגולתא & (=) סגולתא & (=) סגולתא & גולתא & 4. סִגוֹלְתָּא \\
\hline ירח בן יומו & (=) פזר גדול & (=) פזר גדול & פזר גדול & 5. פְִּּר גָדוֹל \\
\hline ) דרגא & (=) ירח בן יומו & (=) ירח בן יומו & (=) ירח בן יומן & 6. יָרחַ בֶּן יוֹמוֹ \\
\hline ) תביר & 1 & (=) קרני פרה & קרני...פרה & 7. בַרְנִי פָּרָה \\
\hline (14) שופר מהופך & & געיה & & 8. גַעִעיָה \\
\hline פזר גדול & (=) תלישה & (=) תלשא & (=) תלשא & 9. הַתְְשׁא \\
\hline (24) מאריך & (=) אזלא & 1) פסקא & אזלא & 10. אַזְלָא \\
\hline & & & & 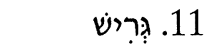 \\
\hline (26) א & & (10) אזלא & ) פסק & 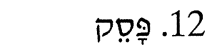 \\
\hline (11) גרי & (=) רביע & (11) גריש & (=) רביע & 13. רְבִיעַ \\
\hline (13) רביע & (=) שופר מהופך & (=) מהופך שופר & (=) שופר הפוך & 14. שוֹפָר מְהוּפּּך \\
\hline (29) יתיב & (=) קדמא & (=) קדמא & (=) קדמא & 15. קָדְמָא \\
\hline (27) רפה & (=) תרי קדמין & $-(16)$ & $-(16)$ & 16. תָּרֶרי קָדְמִין \\
\hline (32) מפיק בה' & (=) זקר קטון & (=) זקף קטון & (=) זקף קטון & 17. זָקְר קָט \\
\hline
\end{tabular}

23 With few exceptions only. 


\begin{tabular}{|c|c|c|c|c|}
\hline אהה עלי כי נקף & - ז האמה & פלאך קיוויתי & קודר הילכתי & Zarca List \\
\hline (21) תרי טעמין & (=) זקף גדול & (=) זקר גדול & ) (=) וגדול & 18. זָסְר גָּדוֹל \\
\hline (15) קדמה & (=) שלשלת & (=) שלשלת & (=) שלשלת & 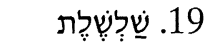 \\
\hline (16) תרי קדמין & (=) שני גרישין & (=) שני גרושין & (=) שני גרישין & 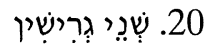 \\
\hline (10) אזלא & (=) תרי טעמי & (=) תרי טעמין & (=) תרי טעמי & 21. תְּרֶרי טַעִמִִּ \\
\hline (7) קרני פרה & (=) דרגא & (23) תביר & (=) דרגא & 22 \\
\hline (12) פסק & $-(23)$ & (22) דרגא & (=) תביר & 23. תצביר \\
\hline (20) שני גרשין & (=) מאריך & (=) מאריך & (=) מאריך & 24. מַאַריך \\
\hline (19) שלשלת & ('=) טרחא & (=) טרחא & (=) טרחא & 25. טרחא \\
\hline (8) געיא & (=) אתנח & (=) אתנח & (29) יתיב & 26. אַתְנְח \\
\hline (9) תלשא & ) (=פא (=) & (=) רפה & (26) אתנח & 27. רֶפֵא \\
\hline (29) יתיב . & $-(28)$ & (=) דגש & (27) רפה & 28. \\
\hline (30) תרצה & (=) יתיב & (=) יתיב & $-(28)$ & 29. יְתִיב \\
\hline (33) שיבה & (=) תרצא & (=) תרצה & $-(30)$ & 30. דּרְָָּא \\
\hline (18) זקף גדול & (=) שבולת & (=) שבולת & \multicolumn{2}{|c|}{ 31. שבּוֹלְת/שִּבוֹלְת (31) - } \\
\hline (31) שבולת & (=) מפיק & (=) מפיק & $-(32)$ & 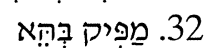 \\
\hline (34) סוף פסוק & (=) שבא ... געיה & $-(33)$ & $-(33)$ & 33. שְׁבָא 24 \\
\hline$-(17)$ & (=) סוף פסוק & $-(34)$ & $-(34)$ & 34. סוֹף פּסוּק \\
\hline$-(28)$ & & & & \\
\hline
\end{tabular}

According to Zafrani 1984 (p. 81) the connection between Jewish thought and poetry has two representations, and it is therefore possible to distinguish between poetry based on Jewish tradition in general, and poetry based on one specific traditional subject. The latter category (according to Zafrani) is purely pedagogical and is used predominantly as a mnemonic device. Thus, the four poems discussed

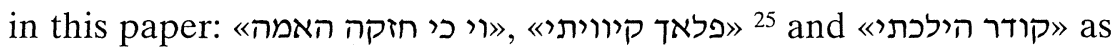
well as belong to the second category, for they all focus on the specific subject of biblical accentuation.

\footnotetext{
${ }^{24}$ In the Zarca List שבא is allways combined with גבעיה (שעיה/געיה שבא גבאיה), to

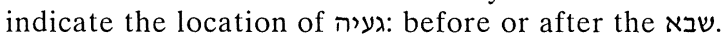

25 is a sixteenth century reference to the Sephardi Zarca List. I am unfamiliar with any earlier texts referring to this list; however, it is important to mention that considerable parts of this list can be found in Sefer ha-Zohar (ti-

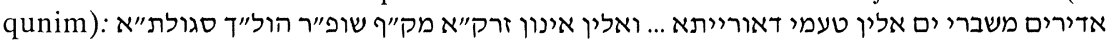

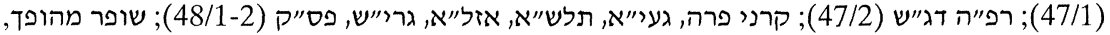

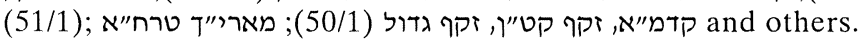


However, as already mentioned, the first three poems follow the Zarca List almost accurately, and therefore clearly illustrate their didactic goal - «form» is an important element in these poems, and it seems as if their purpose is to help memorize the Zarca List. ${ }^{26}$ As for «"אהה עלי כי נקף, the epigraph does indeed suggest a reference to the accentuation system «ותעש גם היא מטעמים מקוסף", and the opening sentence «ז זרקא מקף שופר הולך סגולתאי, as well as the use of the «Geršayim» in the sign names are an explicit reference to the Zarca List. Yet, the poetic freedom concerning the order of their appearance (and to a certain extent their contextual interpretation) creates a more balanced poem in terms of the relationship between «form» and «content», a poem in which the names of accents and diacritical signs serve as a mnemonic device, as well as an illustration of the people's agony and hope for salvation.

\footnotetext{
${ }^{26}$ Rabbi Ja'acov Ben-Me'ir (Rabenu Tam) specifically claims to have written מחברת (an essay) for accentuation rules according to the «Massora» (בעל פי מסורת). In this case the poem deals with biblical accentuation, and these signs are its

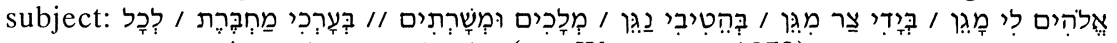

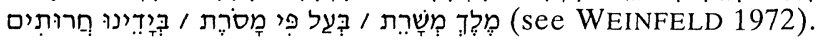




\author{
Appendix 27

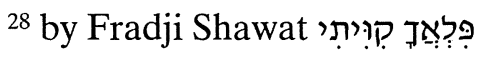 \\ פלאך קויתי דגלי רוממה / צור פלאיך מכל חי נשגבו

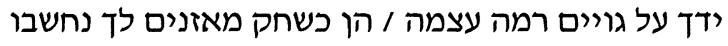 \\ רב להושיע מה יקר חסדך / אל מדבר בצדקה צאנך פרק

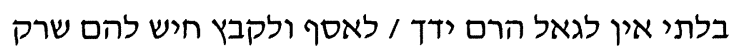 \\ 5 \\ בעדם הקיפם מקף נאמה / איך שמע שופר הולך יתאבו \\ עוד היות לסגולתא נאה נעמה / עם בפזר גדול חלו נכאבו \\ גואלי חי בשר כי אז נהיה / נו"ן לירח בן יומו ורי"ש

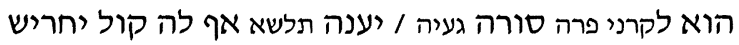

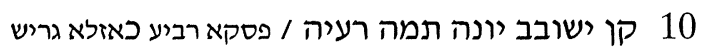 \\ לה מהפך שופר כונן קוממה / מעפרים עם מעצבה שכבו

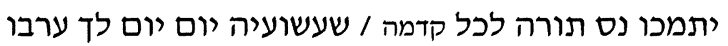 \\ יה בזקף קטון עד אן עמך / בזקף גדול כי רב דללו

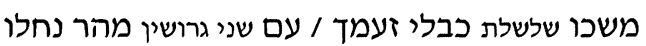

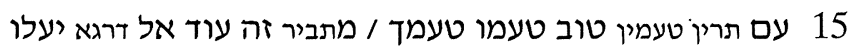

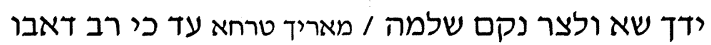 \\ חיש ביום אתנח את לבם נחמה / בו יגיעי כח נח ישובו \\ חזקו לב רפה מר לי יעטף / מנשא על דגש יונה יוחלה

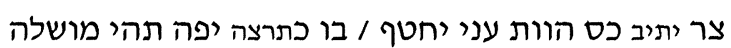

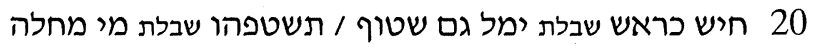

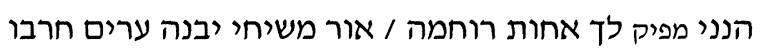

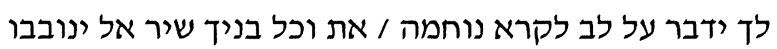

${ }^{27}$ Since I have not seen the manuscripts, the songs are quoted from the sources mentioned below (without the punctuation). The names of the signs are written here in a different font.

${ }^{28}$ Quoted from HaZAN 1995, pp. 220-222. 
Sef 62:2 (2002) NAMES OF ACCENTS AND DIACRITICAL PUNCTUATION SIGNS IN POEMS... 365

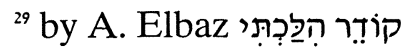

קודר הלכתי / על אמה חצים עלי זרקא

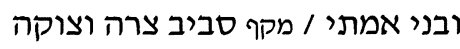

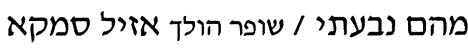

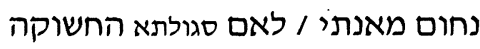

5

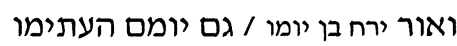

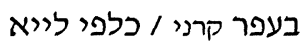

ובית מלוני / שם פרה געיא

מחמדי עיני / תלשא בצדיה מלוני / שם געיא

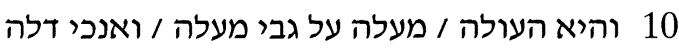

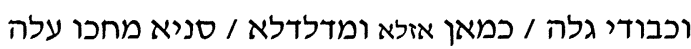

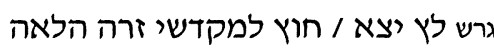

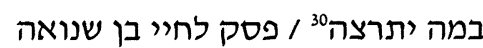

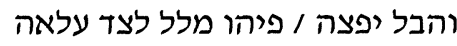

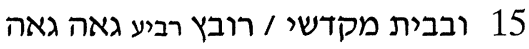

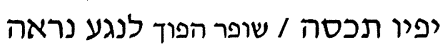

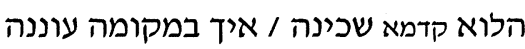

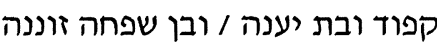

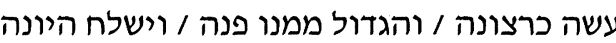

20 זקף יתמחי / קטון וגדול בשמי קורה

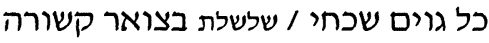

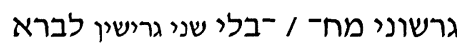

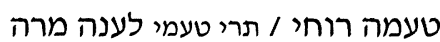

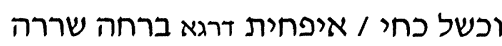

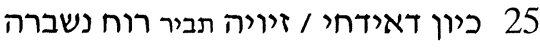

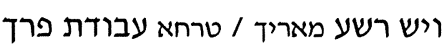

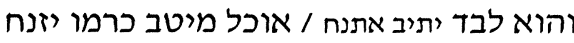

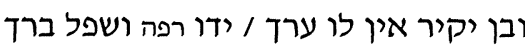

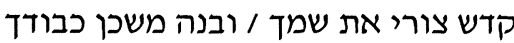

30 ואזי נשיר לך / יתברך שמך

${ }^{29}$ Quoted from Shoshanna 1979, pp. 322-324.

30 יתרצה: perhaps it is the poet's way of alluding to תרצה. 


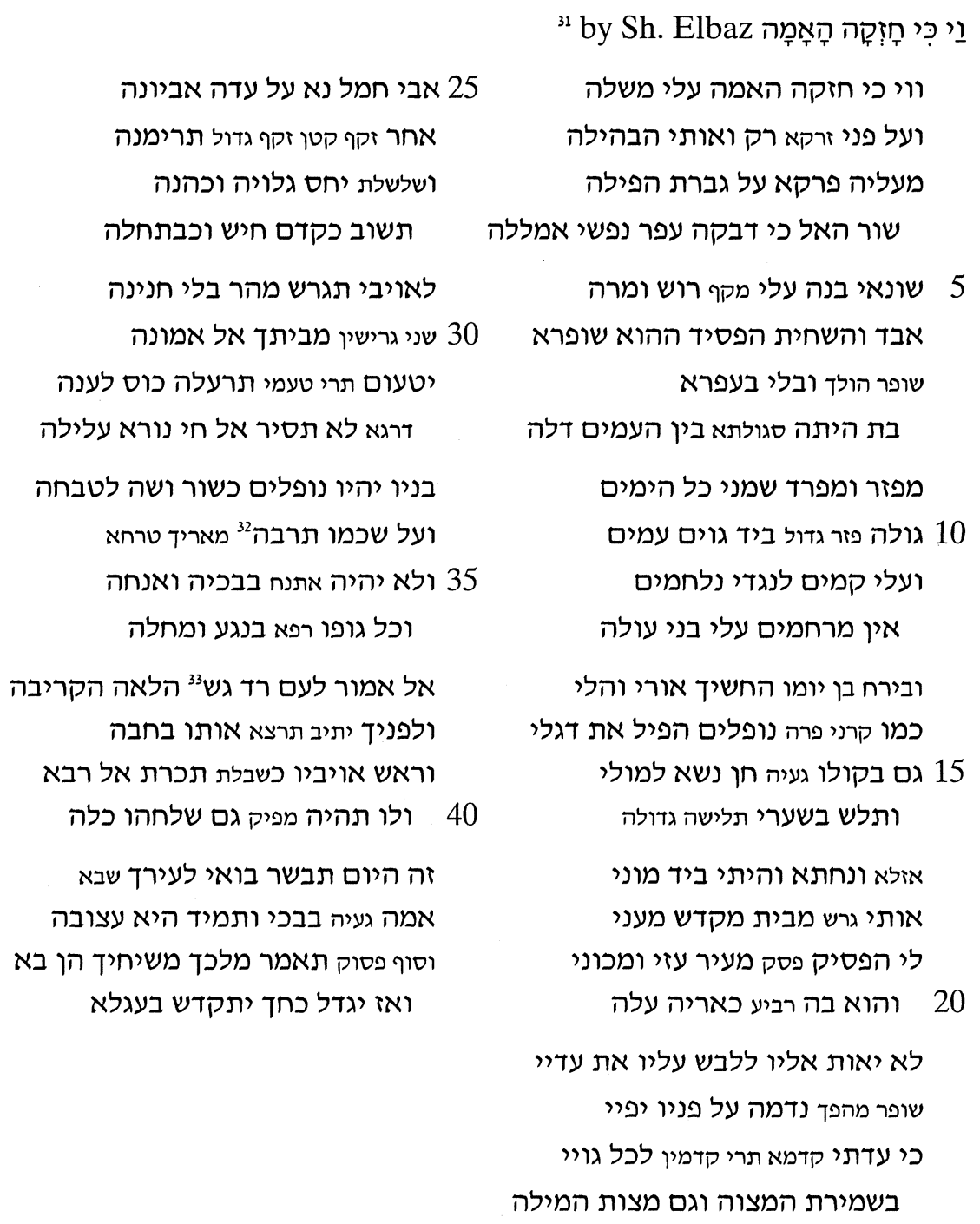

${ }^{31}$ by Sh. Elbaz וַי פִּי חָזְקָה הָאָָמדה

ווי כי חזקה האמה עלי משלה

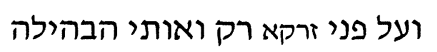
מעליה פרקא על גברת הפילה הפיה הפיה

שור האל כי דבקה עפר נפשי אמללה

5

אבד והשחית הפסיד ההוא שופרא שופר הולך ובלי בעפרא וחשית חפיד

בת היתה סגולתא בין העמים דלה

מפזר ומפרד שמני כל הימים

10 גולה פזר גדול ביד גוים עמים ועלי קמים לנגדי נלחמים גולד גודים

אין מרחמים עלי בני עולה

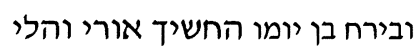

כמו קרני פרה נופלים הפיל את דגלי נורי וחלי

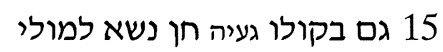
ותלש בשערי תלישה גדולה

אזלא ונחתא והיתי ביד מוני אותי גרש מבית מקדש מענית ביר מירי לי הפסיק פסק מעיר עזי מדי ומכוני 20

לא יאות אליו ללבש עליו את עדיי

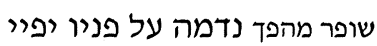
כי עדתי קדמא תרי קדמין לכל גויי בשמירת המצוה וגם מצות המילה לכל גויל

\footnotetext{
31 Quoted from AdARy 1997, pp. 207-209.

32 Perhaps תרבה ת תבר since תביר should be located between

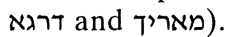

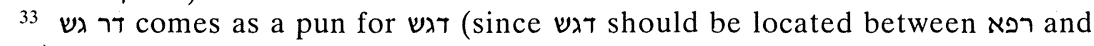
יתיב).
} 


\section{REFERENCES}

ADARY 1997: Sh. AdARY, «Reshut» to «Kadish» Poetry in the Heritage's Poetry of Rabbi Shmuel Bar Yehuda Elbaz, on the Background of the Habit to Include Poetry Heritage in Prayer in the Moroccan Judaism, M.A. Thesis, Bar-Ilan Univesity (Ramat Gan 1997) [in Hebrew].

Dotan 1967: A. Dotan, The Diqduqé Hattěamim of Ahăron Ben Mošé Ben Aser with a Critical Edition of the Original Text from New Manuscripts (Jerusalem 1967) [in Hebrew].

DotAN 1971: A. DotAN, «Masora», Encyclopaedia Judaica, vol. 16 (1971) cols. 1401-1482.

HAZAN 1976: E. HAZAN, The Poems of Fradji Shawat Critical Edition with Introduction and Commertary (Jerusalem 1976) [in Hebrew].

HAZAN 1987: E. HAZAN, «Hebrew Letters, Vowels and Accents as Poetical Similes», in Language Studies II-III, ed. M. BAR-AsHER (Jerusalem 1987) pp. 367-37.5 [in Hebrew].

HAZAN 1989: E. HAZAN, The Piyyutim of Rabbi Musa Bujanah Edited with Introduction and Notes (Jerusalem 1989) [in Hebrew].

HaZAn 1995: E. HaZAn, Hebrew Poetry in North Africa (Jerusalem 1995) [in Hebrew].

KATZ, 1977: K. KATZ, The Hebrew Language Tradition of the Community of Djerba (Tunisia), in לשון ועדה II, Publication of the Hebrew University Language Traditions Project, ed. Sh. MORAG (Jerusalem 1977) [in Hebrew].

MASHIAH and LAVI 1998: R. MASHIAH and T. LAVI, «Zarqa Maqaf Shofar Holekh Segolta: The Sefaradic Luah ha-Zarqa in a Piyyut by Refael Aaron Monsonyego», Lěsonénu 61 (Jerusalem 1998) pp. 61-71 [in Hebrew].

SChirmann 1961: J. Schirmann, The Hebrew Poetry in Spain and Provence (Jerusalem 1961) [in Hebrew].

Shoshanna 1983: Ch. R. Shoshanna, אעירה השחר (Jerusalem 1983) [in Hebrew].

WEINFELD 1972: J. WeINFELD, טעמי המקרא (Biblical Accents) (Jerusalem 1972) [in Hebrew].

WiCKES 1887: W. WiCKES, טעמי כ"א ספרים A Treatise on the Accentuation of the twenty-one so-called Prose Books of the Old Testament (Oxford 1887, repr.: New-York 1970). 
Zafrani 1984: H. Zafrani, Poésie Juive au Maroc (Jérusalem 1984) [in Hebrew].

\section{RESUMEN}

En varias ediciones impresas sefardíes del Pentateuco hay una lista de treinta y cuatro nombres de acentos y de signos diacríticos de puntuación. Esta lista se denomina la Lista de Zarca, por el nombre del primer acento que se menciona. He hallado cuatro poemas basados en esta lista: פלאך קיוויתי, escrito por el poeta tunecino Fradji Shawat (siglo XVI); וי כי חזקה האמה, escrito por el poeta marroquí Shumu'el Elbaz (siglo XIX); קודר הילכתי, probablemente escrito por el poeta marroquí Amram Bar-Yehuda Ezbaz (siglo XIX); y אהה עלי כי נקף, cuyo autor es el poeta marroquí Rafael Aaron Monsoñego (siglo XIX). En los cuatro poemas se atribuyen significados literarios y figurados a los nombres de los signos.

Los tres primeros poemas siguen casi exactamente la Lista de Zarca, y en ellos la «forma» es un elemento importante, ya que parece ser que su propósito es ayudar a memorizar la Lista. Respecto a אהה עלי כי נקף, la libertad poética que caracteriza el orden de los nombres de los signos (y, en cierta medida, la interpretación contextual) se traduce en un poema más equilibrado en cuanto a la relación entre «forma»y «contenido».

PALABRAS ClAVE: Lista de Zarca, Monsoñego, poetas marroquíes, acentos, signos diacríticos, puntuación.

\section{SUMMARY}

In several Sephardi printed editions of the Pentateuch one can find a list of thirty-four names of accents and diacritical punctuation signs. This list is called the Zarca List, named after its opening accent. I have come across four poems based on this list: פלאך קיוויתי, written by the Tunisian poet Fradji Shawat (sixteenth century); וי כי חזקה האמה, written by the Moroccan poet Shmu'el Elbaz (nineteenth century); קודר הילכתי, probably written by the Moroccan poet Amram Bar-Yehuda Elbaz (nineteenth century); and אהה עלי כי נקף, written by the Moroccan poet Rafael Aaron Monsoñego (nineteenth century). In all four poems both literal and figurative meanings may be ascribed to the names of the signs.

The first three poems follow the Zarca List almost accurately; «form» is an important element in these poems, and it seems as if their purpose is to help memorize the Zarca List. As for אהה עלי כי נקף the poetic freedom concerning the order of the sign names (and to a certain extent their contextual interpretation) creates a more balanced poem in terms of relationship between «form» and «content».

KEYWORDS: Zarqa List, Monsonyego, Moroccan poets, accents, diacritical signs, punctuation. 